\title{
Article
}

\section{China's U-shaped Line in the South China Sea Revisited}

Zou, Keyuan

Available at http://clok.uclan.ac.uk/3144/

Zou, Keyuan ORCID: 0000-0002-2868-4948 (2012) China's U-shaped Line in the South China Sea Revisited. Ocean Development and International Law, 43 (1). pp. 18-34.

It is advisable to refer to the publisher's version if you intend to cite from the work. http://dx.doi.org/10.1080/00908320.2012.647483

For more information about UCLan's research in this area go to http://www.uclan.ac.uk/researchgroups/ and search for < name of research Group>.

For information about Research generally at UCLan please go to http://www.uclan.ac.uk/research/

All outputs in CLoK are protected by Intellectual Property Rights law, including Copyright law. Copyright, IPR and Moral Rights for the works on this site are retained by the individual authors and/or other copyright owners. Terms and conditions for use of this material are defined in the policies page.

\section{CLoK}

Central Lancashire online Knowledge www.clok.uclan.ac.uk

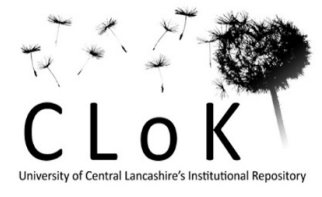




\title{
INTERNATIONAL LAW IN THE CHINESE DOMESTIC CONTEXT
}

\author{
Zou Keyuan*
}

ABSTRACT

The effectiveness of international law depends on its implementation and enforcement by nation-states, including those within the domestic domain. In recent years, the United Nations (hereinafter " $U N$ ") called on its member states to achieve rule of law at both the national and international levels. As a rising power, China has recently been the subject of international attention. In particular, because China is now seen as a responsible stakeholder for the world community, the attention has concerned China's behaviour and acts under international law. This Essay examines China's practice in international law at the national level through its legislature, administration, and judiciary and also explores the gaps and inconsistencies, with reference to the implementation and application of international human rights law in China.

\section{INTRODUCTION}

International law was introduced to China in the late nineteenth century by Western missionaries. In 1864, W.A.P. Martin translated Henry Wheaton's Elements of International Law into Chinese, and it was published by the Tsungli Yamen. ${ }^{1}$ Later, the founding of the People's Republic of China (hereinafter "PRC") ushered in a new era for the application of international law in China. Thus, China declared itself a socialist country and created a socialist domestic legal system that was greatly influenced by the Soviet Union, particularly in the early years of the PRC. Likewise, international law studies in China reflect a tendency to align with the Soviet Union as well as differences with Western and universal legal principles. Only after the economic reform and opendoor policy were enacted in the late 1970s has China become more compliant with universally accepted principles of international law.

Since 1978, China has participated in the UN and other international organisations. China attended various treaty-making conferences

* Harris Professor of International Law, University of Central Lancashire, Preston, United Kingdom. An earlier version of this Article was presented at the Conference on "International Law in the Domestic Context," which was organised by and held at the Valparaiso University School of Law on April 3, 2009.

1 Though before that time, scattered translations of international law works had appeared in China, but Martin's work is regarded as the "formal and systematic introduction of international law" into China. See INTERNATIONAL LAW 43 (Wang Tieya ed., 1995). 
sponsored by either the UN or other world governmental organisations, such as: the Third United Nations Conference on the Law of the Sea (1973-1982), which adopted the landmark UN Convention on the Law of the Sea; the United Nations Conference on Environment and Development in 1992, which adopted the UN Framework Convention on the Climate Change and the Convention on Biological Diversity; and the Rome Conference on the Establishment of the International Criminal Court in 1998, which adopted the Statute of the International Criminal Court. $^{2}$

On the other hand, China acceded to or ratified a number of multilateral treaties in various fields ranging from maritime matters, outer space and aviation, environmental protection, and economic development to international cooperation, human rights, and judicial assistance. According to a source, China is party to 273 multilateral international treaties, of which 239 became applicable to China only after 1979.3 What is remarkable in China's participation in international treaties is its signing of the International Covenant on Economic, Social, and Cultural Rights (hereinafter "ICESCR") and the International Covenant on Civil and Political Rights (hereinafter "ICCPR"), which were adopted by the UN in 1966. ${ }^{4}$ Nevertheless, the Covenants are not binding on China until the completion of the ratification process, but China's participation indicates a sincere intention to abide by these two conventions. Although China has ratified the ICESCR, the whole world is still keeping a close eye on how China will implement it at the domestic level.

The rule of law within a nation-state depends on the development of international law in the world community and participation in the process of law-making at the global level. Once a state signs and ratifies an international treaty, it is bound by that treaty and must implement it at the domestic level. In Chinese practice, a treaty is superior to municipal law in application, though the Chinese Constitution has no express provision on the relative status of treaties and laws. ${ }^{5}$ The 1986 General Principles of Civil Law provide that if any treaty concluded or acceded to by China contains provisions different from those in the civil

2 See James V. Feinerman, Chinese Participation in the International Legal Order: Rogue Elephant or Team Player?, in CHINA'S LEGAL REFORMS 186-210 (Stanley B. Lubman ed., 1996).

3 See generally Hanqin Xue, China's Open Policy and International Law, 4 CHINESE J. INT'L L. 136 (2005).

$4 \quad$ China signed the former in October 1997 and the latter in October 1998.

5 See WANG TIEYA, INTERNATIONAL LAW IN CHINA: HistoriCAL AND CONTEMPORARY PERSPECTIVES (1990). 
laws of China, the provisions of the international treaty shall apply, unless they are ones to which China has made reservations. ${ }^{6}$

The problem is how to implement international treaties in China. China has to make necessary domestic laws or guidelines to implement the relevant international treaties to which it is a party. For example, with respect to the UN Law of the Sea Convention, China was involved in the making of this Convention, and it was ratified by China in 1996. At the domestic level, however, China promulgated the Law on the Territorial Sea and the Contiguous Zone and Law on the Exclusive Economic Zone and the Continental Shelf in $1992^{7}$ and in 1998 respectively. ${ }^{8}$ In 1996, China also adopted Ocean Agenda 21 following the 1992 Rio world document Agenda 21, and, more significantly, for the first time in 1998 issued a White Paper on the development of marine affairs. ${ }^{9}$ All these domestic commitments are ways of implementing the UN Law of the Sea Convention. It is necessary for domestic laws and regulations to be consistent with the relevant international treaties. If they are not yet, then they must be revised or amended to bring them into line with the treaties being implemented. This Essay examines the recent Chinese practice of implementing international law at the domestic level, with special reference to the application of international human rights law.

\section{MEANS OF IMPLEMENTATION}

Generally, there are two approaches to the relationship between international law and municipal law: the monist approach (hereinafter "monism") and the dualist approach (hereinafter "dualism"). According to the former, international law is part of domestic law, and there is no division between the two; the latter holds that international law and municipal law exist separately, and international law has to be transformed to be domestic for the purpose of its implementation at the domestic level. ${ }^{10}$ There is a third approach, however, that attempts to modify the dualist position by "denying that any common field of operation exists as between international law and municipal law by which one system is superior or inferior to the other."11 The majority of

6 Article 142 of the General Principles of Civil Law, in THE LAWS OF THE PEOPLE'S REPUBLIC OF CHINA 291 (1983-1986).

7 For the full text, see Robert W. Smith, Limits in the Seas, No. 117, Straight Baselines Claim: China, 11-14 (1996).

8 For the full text of the Law on the Exclusive Economic Zone and the Continental Shelf, see Zou Keyuan, CHINA's MARINE LEGAL SYSTEM AND THE LAW OF THE SEA 342-45 (2005).

9 See CHINA DAILY, May 29, 1998.

10 See Malcolm N. SHaW, 6 InTERnATIONAL LAW 131-32 (1998); WANG Tieya, INTRODUCTION TO INTERNATIONAL LAW 180-92 (1998).

11 SHAW, supra note 10 , at 132. 
Chinese scholars tend to adopt this approach, concluding that though the two systems are different they are closely linked and infiltrate and supplement each other because both laws are made by the States, collectively or individually. ${ }^{12}$

The above Chinese approach is actually reflected in China's practice. It is unclear whether international law is part of the Chinese legal system because the Chinese Constitution does not touch upon the relationship between international law and municipal law. Nevertheless, China accepts the general rule of international law that a State is bound by a treaty it has acceded to and thus has the obligation thereto. China acceded to the 1969 Vienna Convention on the Law of Treaties and it obliges China to comply with its treaty obligations and to prevent evasion of its obligations by using its domestic laws as a justification. A typical example to reflect the Chinese position on the implementation of international law is an oft-quoted provision contained in the Chinese General Principles of Civil Law promulgated in 1986, Article 142, which provides:

If any international treaty concluded or acceded to by the People's Republic of China contains provisions differing from those in the civil laws of the People's Republic of China, the provisions of the international treaty shall apply, unless the provisions are ones on which the People's Republic of China has announced reservations. International practice may be applied to matters for which neither the law of the People's Republic of China nor any international treaty concluded or acceded to by the People's Republic of China has any provisions. ${ }^{13}$

Though the above is often quoted, the first law to contain such a clause was actually the 1982 Chinese Law on Civil Procedure. Chinese scholars use this clause to demonstrate that international treaties can be directly applicable in China. ${ }^{14}$ Second, in case there is a conflict between

12 WANG, supra note 10, at 191-92.

13 English text available at General Principles of the Civil Law of the Peoples Republic of China, http://www.law-bridge.net/english/ (last visited Nov. 4, 2009).

14 See WANG, supra note 10, at 208. Evidence of direct application of international treaties in China is the Provisions on the Use of Red Cross Signs issued jointly by the State Council and the Central Military Commission in 1996, Article 23 of which provides "[i]f there is anything concerning the protective use of Red Cross signs not covered in these Provisions, the relevant provisions of the Geneva Conventions and their Additional Protocols shall apply." Id. 
treaty law and domestic law, the treaty law should prevail except when China has made reservations. Finally, the above clause reveals that China recognises the validity of international customary law to certain extent as it provides that international practice may be applied to subject matters when no applicable law could be found in either Chinese law or any treaty concluded or acceded to by China. It is unclear, however, whether China recognises the application of all norms and rules of international customary law. According to some observations, it only refers to customary rules of international trade based on China's judicial practices. ${ }^{15}$

From the above, we may draw some brief general observations. First, there is no doubt that China respects international law. Second, international law can be applied in China but is limited to those treaties to which China is a party. Third, if there is a conflict between a treaty China has acceded to and China's relevant domestic law, the treaty prevails. But this may not lead to the conclusion that China recognises the prevailing force of international law over its domestic law because treaties are only part of the body of international law. According to one observation, "treaties acquire prevailing force over domestic law only when the relevant domestic law includes an explicit stipulation to that effect. In other words, conflict rules operate only to the extent of the specific laws concerned." 16 Fourth, the picture about the application of international customary law is not clear. It seems that China's courts apply some customary rules governing international trade, such as the Hague-Visby Rules. Also, Chinese contract law contains a clause that permits the parties to a contract with foreign elements to choose applicable law for the settlement of their disputes arising from the contract, and they may choose a customary rule of international trade as the applicable law. ${ }^{17}$

In addition to the application of the treaties to which China is a party, China has transformed some treaties into domestic laws. This practice is manifested by the promulgation of the two domestic laws concerning diplomatic and consular affairs: the 1986 Regulations concerning Diplomatic Privileges and Immunities, and the 1990 Regulations concerning Consular Privileges and Immunities. ${ }^{18}$ As we know, China joined the 1961 Vienna Convention on Diplomatic Relations

15 See Xue Hanqin \& Jin Qian, International Treaties in the Chinese Domestic Legal System, 8 CHINESE J. INT'L L. 299, 303 (2009).

16 See id. at 305.

17 See Contract Law of the People's Republic of China 1999 art. 126(1).

18 English texts available at, http://www.fmprc.gov.cn/chn/wjb/zzjg/tyfls/tfsckzlk/ xggnlf/t70823.htm; http:// www.fmprc.gov.cn/chn/wjb/zzjg/tyfls/tfsckzlk/xggnlf/t7082 4.htm. 
and the 1963 Vienna Convention on Consular Relations respectively in 1975 and 1979. China incorporated the main contents of the two Conventions into its Regulations. China's second practice to endorse international law is to adopt relevant international norms and rules in its domestic law. This can be seen from the promulgation of Chinese laws concerning maritime law: the 1992 Law on the Territorial Sea and Contiguous Zone, and the 1998 Law on the Exclusive Economic Zone and Continental Shelf, which incorporated relevant provisions of the 1982 UN Convention on the Law of the Sea. There is a difference between the above two categories: while the former two regulations just follow the two treaties on diplomatic and consular affairs, the latter two laws only incorporate parts of the UN Law of the Sea Convention.

Another way of implementing international law at the domestic level is to maintain relevant domestic laws in line with the treaties that China has joined or is expected to join. If there is any inconsistency, relevant domestic laws should be amended or even annulled. In preparation for joining the World Trade Organization (hereinafter "WTO"), China launched the overall review process of its laws and regulations as early as 1999. Many administrative regulations and measures either by the Chinese State Council or various ministries were annulled before the end of 2000.19 Since its entry into the WTO, China has quickened its pace of revising its existing laws and regulations. According to a statistic, as of the end of 2002, China had revised fourteen laws and thirty-seven administrative regulations, annulled twelve administrative regulations, suspended thirty-four relevant documents, and changed more than one thousand departmental rules and measures. ${ }^{20}$ Meanwhile, new laws have to be timely adopted to cope with the changed situation. As one Justice of the Chinese Supreme Court commented, the biggest change after the WTO entry would be in the legal environment. ${ }^{21}$

In the Report of the Working Party on the Accession of China, China expressed its official position on the implementation of the WTO laws and regulations:

The representative of China stated that China had been consistently performing its international treaty

\footnotetext{
19 See State Council, Decision on Annulling Partial Administrative Regulations and Measures Promulgated before the End of 2000, http://www.npcnews.com.cn/gb/paper228/1/index. htm (last visited Nov. 23, 2001).

20 See Fulfilling the Promise for the WTO Entry in the Legal System, China Has Achieved a Remarkable Achievement in Checking $U p$ Laws and Regulations, available at http://www.npcnews.com.cn/gb/paper228/1/class022800001/hwz224162.htm.

${ }_{21}$ Comments of Justice Li Guoguang, available at http://www.npcnews.com.cn/gb/ paper228/1/index.htm.
} 
obligations in good faith. According to the Constitution and the Law on the Procedures of Conclusion of Treaties, the WTO Agreement fell within the category of "important international agreements" subject to the ratification by the Standing Committee of the National People's Congress. China would ensure that its laws and regulations pertaining to or affecting trade were in conformity with the WTO Agreement and with its commitments so as to fully perform its international obligations. For this purpose, China had commenced a plan to systematically revise its relevant domestic laws. Therefore, the WTO Agreement would be implemented by China in an effective and uniform manner through revising its existing domestic laws and enacting new ones fully in compliance with the WTO Agreement.

The representative of China confirmed that administrative regulations, departmental rules and other central government measures would be promulgated in a timely manner so that China's commitments would be fully implemented within the relevant time frames. If administrative regulations, departmental rules or other measures were not in place within such time frames, authorities would still honour China's obligations under the WTO Agreement and Draft Protocol. The representative of China further confirmed that the central government would undertake in a timely manner to revise or annul administrative regulations or departmental rules if they were inconsistent with China's obligations under the WTO Agreement and Draft Protocol. 22

After having entered into the WTO in 2001, China has repealed, revised, and adopted more than three thousand domestic laws, administrative regulations and rules that are related to the principles and rules of the WTO.

In August 2002, the Chinese Supreme Court issued the Decision on Certain Issues of Handling Administrative Cases of International Trade, which was the first decision relating to the handling of trade cases in line with the WTO regulations. Article 9, particularly relevant to the

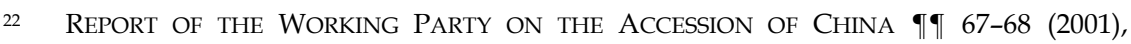
http://www.cecc.gov/pages/selectLaws/WTOimpact/wkptrptPRCWTO.php. 
implementation of international law in China, provides that when there are two reasonable interpretations in a particular applicable rule from a national law or administrative regulation in the handling of administrative cases of international trade; if one of the interpretations is in conformity with international treaties China concluded or acceded to, then the interpretation in conformity should be applied, except for those on which China has made reservations. ${ }^{23}$ Here the rule of conformable interpretation is used as an alternative to implement relevant international treaties so as to fulfil China's corresponding treaty obligations.

\section{HuMAN RightS TREATIES}

To date, China has acceded to twenty-two treaties on human rights and signed the other two. Also, China has submitted regular national reports as required by five treaties: the ICESCR; the Convention on the Elimination of All Forms of Racial Discrimination (hereinafter "CERD"); the Convention on the Elimination of All Forms of Racial Discrimination against Women (hereinafter "CEDAW"); the Convention against Torture and Other Cruel, Inhuman or Degrading Treatment or Punishment (CAT); and the Convention on the Rights of the Child (hereinafter "CRC") (for a breakdown of these statistics, see Table 1). While China agreed to submit such reports, it complained about the reporting system as an excessively complicated and heavy burden and "certain treaty bodies often exceed their mandates in the exercise of their duties." 24

\begin{tabular}{lc}
\hline Table 1: National Reports Submitted by China; as of October $2008^{25}$ \\
Treaty & Number of submission(s) \\
ICESCR & 1 \\
CERD & 13 \\
CEDAW & 6 \\
CAT & 5 \\
CRC & 2 \\
CRC Protocol & 1 \\
\hline \hline
\end{tabular}

23 See DECISION ON CERTAIN ISSUES OF HANDLING ADMINISTRATIVE CASES OF INTERNATIONAL TRADE (2002), http://www.court.gov.cn/lawdata/explain/executive/ 200303240002.htm (last visited Mar. 27, 2009).

$24 \quad$ See Statement by H.E. Ambassador Liu Zhenmin, Deputy Permanent Representative of China to the United Nations, at the Third Committee of the 63rd Session of the General Assembly under Item on Implementation of Human Rights Instruments, Oct. 21, 2008, available at http://www.china-un.org/eng/hyyfy/t519076.htm.

25 Id. 
In its White Paper on the Rule of Law issued in 2008, China enunciated its basic position on the development of human rights: "placing top priority on people's rights to subsistence and development, making development the principal task, and promoting citizens' political, economic, social and cultural rights to achieve their all-round development." 26 The White Paper lists relevant domestic laws to protect human rights. To safeguard the right to life, there are the Chinese Constitution, the Criminal Law, the General Principles of the Civil Law, the Production Safety Law, and the Law on the Prevention and Treatment of Occupational Diseases. For the safeguard of the right to personal freedom and dignity, there are the Constitution, the Criminal Law, the General Principles of the Civil Law, the Criminal Procedure Law, the Legislation Law, and the Law on Administrative Punishment. In addition, the White Paper specifically mentioned that, in 2003, the Measures for Assisting Vagrants and Beggars with No Means of Support in Cities replaced the old Measures for Taking in and Sending Back Vagrants and Beggars in Cities.

Additionally, for the safeguard of the right to equality, there are the Constitution, the Law on Regional Ethnic Autonomy, and the Law on the Protection of Rights and Interests of Women. For the safeguard of political rights, there are the Constitution, the Legislation Law, the Electoral Law, the Organic Law of the Local People's Congresses and People's Governments, the Law on Assemblies, Processions, and Demonstrations, and the Regulations on Written and Personal Petitions; for the safeguard of freedom of religious belief, there are the Constitution, the Regulations on Religious Affairs, and the Provisions on the Administration of Religious Activities of Aliens within the Territory of the People's Republic of China; for the safeguard of the rights and interests of the working people, there are the Constitution, the Labour Law, the Law on Labour Contracts, the Law on Labour Disputes Mediation and Arbitration, the Law on the Promotion of Employment, the Regulations on Paid Annual Leave of Employees, the Regulations on Labour Security Supervision, the Regulations on Work-related Injury Insurance, the Regulations on Unemployment Insurance, the Provisional Regulations on Collection and Payment of Social Insurance Premiums, the Interim Measures on Maternity Insurance for Enterprise Employees, the Regulations on the Employment of the Disabled, Provisions on the Labour Protection of Female Employees, and the Provisions on the

26 White Paper Published ON China's Rule OF LAW, Feb. 28, 2008, http://www.china.org.cn/government/news/2008-02/28/content_11025486.htm (follow "III. Legal Systems of Respecting and Safeguarding Human Rights" hyperlink under "China's Efforts and Achievements in Promoting the Rule of Law"). 
Prohibition of Child Labour. For the safeguard of economic, social, cultural, and other rights, there are the Constitution, the Property Rights Law, the Law on the Protection of the Rights and Interests of the Elderly, the Law on Maternal and Infant Health Care, the Law on the Protection of Minors, the Law on the Protection of the Disabled, the Regulations on the Minimum Standard of Living of Urban Residents, the Regulations on Rural "Five-Guarantee" Work, the Regulations on Special Care and Preferential Treatment for Servicepersons, the Regulations on the Placement of Demobilized Compulsory Servicepersons, and the Compulsory Education Law. ${ }^{27}$

From the above, we can see that China does not enact a general law for the protection of human rights. There is no such thing as a Bill of Rights or Human Rights Act in China. Rather, relevant Chinese laws and regulations embody certain human rights principles, norms, and standards. This fragmented approach may unfavourably affect the effectiveness of the international human rights law applicable in China.

Nevertheless, it is generally admitted that while China has achieved a great deal in the protection and improvement of human rights in accordance with international human rights law, there is much room for improvement. This is why China is criticised by the United States and relevant international organizations for its poor human rights record.

\section{GAPS IN IMPLEMENTATION: THE RE-EDUCATION THROUGH LABOUR SYSTEM}

While there are many aspects that can be used to examine China's practice in implementing international human rights law, the Reeducation Through Labour System (hereinafter "RTL"), is an example of where China fails to fulfill its obligation under international human rights law. The RTL consists of a set of administrative measures that subject people who have violated laws or disciplines, but are not subject to criminal liability, to compulsory "reform through labour." 28 The RTL can also be defined as a kind of punishment for those offenders who are not subject to criminal liability or whose offences are not serious enough for the imposition of criminal liability. ${ }^{29}$ The 1982 Interim Measures on Re-education Through Labour prepared by the Chinese Ministry of Public Security and passed by the Chinese State Council defined RTL as

27 See Information Office of the State Council of the PeOple's Republic OF China, White PAPERs of the Chinese Government (1991-1995) (2000) [hereinafter “White PAPERS"].

28 YuAN HONGBing \& SUn XiAONING, CHINESE JUdiCIAL SYSTEM 166 (1988).

29 See Judicial ADMINISTRATIVE WORK OF CONTEMPORARY CHINA 217 (Cai Chen et. al. eds., 1995). 
"an administrative measure to force those who need re-education through labour to compulsory education and reform, and a method to deal with contradictions within the people." 30 The White Paper on Human Rights in China published in 1991, however, regards RTL as merely "an administrative punishment." 31

The RTL system was officially established in August 1957, when the Standing Committee of the National People's Congress (hereinafter "NPC") approved the Decision on Re-education Through Labour prepared by the State Council. There are three key elements to RTL: (a) it is compulsory; (b) it is an administrative measure; and (c) it is used to deal with contradictions within the people. ${ }^{32}$ Although RTL is a measure for those committing minor offences, the police have turned it into a criminal control mechanism. ${ }^{33}$

According to the 1982 Interim Measures on Re-education Through Labour, people who can be put into RTL include: (a) anti-revolutionaries who have committed minor crimes, which are not serious enough for criminal liability; (b) those involved in criminal gangs of murder, rape, robbery, or arson, but are not subject to criminal liability; (c) those who have committed criminal offences such as hooliganism, prostitution, larceny, or fraud, but are not subject to criminal liability; (d) those who have disturbed social order, but are not subject to criminal liability; (e) those who are employed but have refused to work for a long time or violated labour disciplines and disturbed working or production-order, teaching and research order, or have interfered with public affairs; and (f) those who have incited other people to commit crime, but are not subject to criminal liability. ${ }^{34}$ The applicability of RTL was later expanded to other people who needed RTL in accordance with the needs of the situation at different periods, such as prostitutes and their clients, and drug offenders in the 1980s and 1990s. For example, the 1983 Notice issued jointly by the Supreme Court, the Supreme Procuratorate, and the Ministry of Public Security authorised relevant government departments to put into RTL those who illegally removed intrauterine devices used for birth control. ${ }^{35}$

The enforcement arm of RTL was originally the Department of Public Security and was subsequently transferred to the Department of

30 INTERIM MEASURES, COMPENDIUM OF THE LAWS OF THE PEOPLE'S REPUBLIC OF CHINA, art. 2, 1583 (Wang Huai'an et. al. eds., 1989) [hereinafter "INTERIM MEASURES"].

31 WHITE PAPERS, supra note 27, at 86.

32 See YUAN \& SUN, supra note 28, at 169.

33 See generally Victor Dawes \& Sheung Lai Tse, Evaluating the Chinese Criminal Justice System under International Human Rights Standards, 7 ASIA PAC. L. REV. 43 (1999).

34 INTERIM MEASURES, supra note 30, art. 10.

35 Notice No.25 of 1983. 
Justice in July 1983. Currently, there is a Bureau of Management of RTL, which is part of the Ministry of Justice at the central level. Under the leadership of the RTL, management committees and the unified plan of the judicial administrative department, RTL institutions are established to house people subject to RTL.

The most directly relevant human rights convention to the issue is the International Covenant on Civil and Political Rights (hereinafter "ICCPR"), which China signed in 1998 and expressed its willingness on many occasions to ratify soon. Article 8(3) of this Covenant provides that:

a) No one shall be required to perform forced or compulsory labour; b) Paragraph 3 (a) shall not be held to preclude, in countries where imprisonment with hard labour may be imposed as a punishment for a crime, the performance of hard labour in pursuance of a sentence to such punishment by a competent court. ${ }^{36}$

There are two key elements to the above provisions: no one should be forced to work, and a decision on hard labour should be made by a competent court. In the case of RTL, the term "labour," though not clearly defined in law, is usually forced in practice, and a decision on RTL is made by the so-called committee of RTL management. The existing RTL system is obviously not in conformity with the above human rights norm. It is thus predicted that China will have to reform fundamentally, if not abolish, the RTL system upon its ratification of the ICCPR. Even at present, China, though not obliged by the ICCPR, should comply with it bona fide since China has already signed it.

The RTL system is also connected to the issue of proper detention. The Universal Declaration of Human Rights proclaims expressly that "[n]o one shall be subjected to arbitrary arrest, detention or exile." 37 The ICCPR reaffirms the above principle on the one hand, and further details it in a number of legal norms on the other. These include, inter alia, not depriving a person of his liberty "except on such grounds and in accordance with such procedure as are established by law[;]" the right of a person to be detained or arrested to information on the reasons for detention or arrest and on any charges against him; the right of the

36 International Covenant on Civil and Political Rights, Dec. 16, 1966, reprinted in THE RaOUl Wallenberg COMPILATION OF HUMAN RightS INSTRUMENTS 43-60 (Göran Melander \& Gudmundur Alfressson, eds., 1997).

37 Universal Declaration of Human Rights, art. 9, reprinted in THE PROTECTION OF Human RightS IN THE AdMINISTRATION OF CRIMINAL Justice: A COMPENDIUM OF UNITED NATIONS NORMS AND STANDARDS 62 (M. Cherif Bassiouni ed., 1994). 
person who is deprived of his liberty by arrest or detention to take proceedings before a court for a decision whether such arrest or detention is lawful; and the prompt trial of anyone arrested or detained on a criminal charge. ${ }^{38}$ RTL is defined as an administrative measure so that arrest or detention is problematic. What is even more problematic is that a person sentenced to RTL can be sent to an RTL camp without trial.

As to the issue of fair trial, the RTL system has problems too. The Universal Declaration of Human Rights guarantees an equal right for everyone to a fair and public hearing by an independent and impartial tribunal, in the determination of his rights and obligations and of any criminal charges against him. Everyone charged with a penal offence has the right to be presumed innocent until proven guilty according to law. These rights are also embodied in Article 14 of the ICCPR. ${ }^{39}$ Under

38 International Covenant on Civil and Political Rights, supra note 36, art. 9, at 62-63. The UN Human Rights Committee points out that Art. 9(1) is applicable to all deprivation of liberty, whether in criminal cases or in other cases such as, e.g., mental illness, vagrancy, drug addiction, educational purposes, immigration control, etc. Id.

39 Id. art. 14. Article 13 provides that:

1. All persons shall be equal before the courts and tribunals. In the determination of any criminal charge against him, or of his rights and obligations in a suit at law, everyone shall be entitled to a fair and public hearing by a competent, independent and impartial tribunal established by law. The press and the public may be excluded from all or part of a trial for reasons of morals, public order (ordre public) or national security in a democratic society, or when the interest of the private lives of the parties so requires, or to the extent strictly necessary in the opinion of the court in special circumstances where publicity would prejudice the interests of justice; but any judgment rendered in a criminal case or in a suit at law shall be made public except where the interest of juvenile persons otherwise requires or the proceedings concern matrimonial disputes or the guardianship of children. 2. Everyone charged with a criminal offence shall have the right to be presumed innocent until proved guilty according to law. 3 . In the determination of any criminal charge against him, everyone shall be entitled to the following minimum guarantees, in full equality:

(a) To be informed promptly and in detail in a language which he understands of the nature and cause of the charge against him; (b) To have adequate time and facilities for the preparation of his defence and to communicate with counsel of his own choosing; (c) To be tried without undue delay; (d) To be tried in his presence, and to defend himself in person or through legal assistance of his own choosing; to be informed, if he does not have legal assistance, of this right; and to have legal assistance assigned to him, in any case where the interests of justice so require, and without payment by him in any such case if he does not have sufficient means to pay for it; (e) To examine, or have examined, the witnesses against him and to obtain the attendance and examination of witnesses on his behalf under the same conditions as witnesses against him; (f) To have the free assistance of an interpreter 
the RTL system, however, people can be put into RTL institutions without trial. The principle of fair trial does not exist in the RTL system and people subject to RTL are deprived of the right to a fair trial.

Treatment of people who are in RTL institutions seems inconsistent with the standards laid down by the UN. The UN has adopted a series of guidelines dealing with the treatment of prisoners, such as the Standard Minimum Rules for the Treatment of Prisoners, the Basic Principles for the Treatment of Prisoners, the Body of Principles for the Protection of All Persons under Any Form of Detention or Imprisonment, and the Convention Against Torture and Other Cruel, Inhuman or Degrading Treatment or Punishment (hereinafter "CAT").40 Under these UN documents, prisoners should be humanely and fairly treated, and protected from any maltreatment or torture. People subject to RTL, strictly speaking, are not prisoners according to relevant Chinese regulations. In China's practice, however, once a person is put into the RTL system, his treatment is identical to that of prisoners. The management of RTL institutions and of prisons are actually the same, ${ }^{41}$ despite the fact that in December 1988 the Ministry of Justice decided to

if he cannot understand or speak the language used in court; (g) Not to be compelled to testify against himself or to confess guilt. 4 . In the case of juvenile persons, the procedure shall be such as will take account of their age and the desirability of promoting their rehabilitation. 5 . Everyone convicted of a crime shall have the right to his conviction and sentence being reviewed by a higher tribunal according to law. 6 . When a person has by a final decision been convicted of a criminal offence and when subsequently his conviction has been reversed or he has been pardoned on the ground that a new or newly discovered fact shows conclusively that there has been a miscarriage of justice, the person who has suffered punishment as a result of such conviction shall be compensated according to law, unless it is proved that the non-disclosure of the unknown fact in time is wholly or partly attributable to him. 7. No one shall be liable to be tried or punished again for an offence for which he has already been finally convicted or acquitted in accordance with the law and penal procedure of each

Id. country.

40 G.A. Res. 43/173, U.N. Doc. A/RES/43/173 (Dec. 9, 1998); G.A. Res, 45/111, U.N. Doc. A/RES/45/111 (Dec. 14, 1990).

41 This can be seen from various regulations and documents relating to RTL and prison management, e.g., The Decision of the Ministry of Justice on Strengthening the Building-up of the People's Police Team for RTL and Prisons, Mar. 5, 1998, in CHINA SOC'Y ON HUMAN RIGHTS STUDiEs, CHINESE YEARBOOK OF JUDICIAL ADMINISTRATION, 308-10 (2000). The Decision of the Standing Committee of the NPC on Dealing with Persons of Reform through Labour and Persons of RTL Who Have Escaped and Committed Crimes Again treats the crime committed by people released from RTL in the same way as treating recidivism in criminal law. 
separate the management system of RTL from that of Reform Through Labour. 42

There are two points worth mentioning: (1) even treated as prisoners, people subject to RTL should be given certain protection that prisoners enjoy, and (2) since they are not prisoners, their treatment should be better than that of prisoners. Thus, it should be pointed out that the treatment problem is concerned not only with people subject to RTL, but also with all prisoners in China. Though China enacted its Law of Prison in 1994,43 and prison conditions have improved recently, the treatment of prisoners remains a weakness vulnerable to criticism based on human rights law.

That said, China is not allowed to maintain a legal regime that contravenes international human rights laws. The fourth periodic report submitted to the CAT by China in 2007 avoided mentioning the RTL, but then defended this abnormal practice by stating that China has strict regulations on administrative punishment. ${ }^{44}$ Nevertheless, the CAT Committee reiterated its previous recommendations to abolish all forms of administrative detention, including the RTL. ${ }^{45}$

It is worth mentioning that since the 1990s international pressure on China to reform the RTL system has gradually increased. RTL has been a focus of concern among UN human rights bodies and has been a central preoccupation in the human rights dialogues between China and Western countries. The UN Working Group on Arbitrary Detention examined China's RTL system and regarded it as "inherently arbitrary." 46 The International Labour Organisation called for China to stop forced labour under the RTL system and to release labour activists detained under RTL. ${ }^{47}$ All such international pressures can play a positive role in China's RTL reform. To respond to the pressure from

42 See Liu Zhongfa, Survey of the Origin of the RTL System, available at http:/ /211.100.18.62/research/academy/details.asp?lid=1887 (last visited May 9, 2008).

43 CHINESE YEARBOOK OF JUDICIAL ADMINISTRATION, supra note 41, at 368-73.

44 Comm. Against Torture, Consideration of Reports Submitted by States Parties Under Article 19 of the Convention: Fourth Periodic Reports of States Parties due in 2004: China, 34, U.N. Doc., CAT/C/CHN/4 (June 27, 2007).

45 Comm. Against Torture, Consideration of Reports Submitted by States Parties Under Article 19 of the Convention: Concluding Observations of the Committee Against Torture: China, I 13, U.N. Doc., CAT/C/CHN/CO/4 (Nov. 21, 2008), available at http:/ / www2.ohchr.org/ english/bodies/cat/docs/CAT.C.CHN.CO.4.pdf.

${ }_{46}$ Human Rights in China to the Foreign Affairs Committee of the House of Commons, Human Rights Situation in China and the Dialogue on Human Rights, 2 (July 28, 2000), available at http://gb.hrichina.org/old_site/reports/offpleas.html (last visited Mar. 6, 2008).

47 ICFTU v. Pakistan, Case 1903, ILO, Report No. 306, I 495 (1997), available at http://us.ilo.org/news/focus/0108/focus-3.html (last visited Mar. 6, 2008). 
outside, China recently promised to quicken the legal process of ratifying the UN Covenant on Political and Civil Rights. ${ }^{48}$

\section{CHINESE COURTS AND INTERNATIONAL LAW}

The judicial system is a necessary component of the State machinery for governing the country. It can be defined as an "entire network of courts in a particular jurisdiction." 49 The word "judiciary" may have a broader meaning when it is used in conjunction with the term "judicial system"; it refers to the branch of government vested with the judicial power to interpret, construe, and apply the law. ${ }^{50}$ There are two different views in China about the definition of "judicial system": one defines it as the system of organising the people's court, the people's procuratorate, the public security organ and judicial administrative organ and their function of judicial enforcement; ${ }^{51}$ and the other narrows it to include only the organisation and activities of the court and the procuratorate..$^{52}$

Despite the different views, courts are no doubt an essential part of the judicial system in China. The People's Court is founded in accordance with the Chinese Constitution. ${ }^{53}$ The Court, as mandated by the Constitution, is the judicial organ of the State, and includes the Supreme Court, courts at various local levels, military courts, and other special courts, such as maritime courts and railway transport courts. It has four levels: the Supreme Court; the higher courts at the provincial level (a total of thirty-one); intermediate courts at the prefectural level (389); and primary courts at the county level (3067). The Supreme Court, ${ }^{54}$ which is the highest court, supervises the administration of justice by local and special courts. Courts at the higher level supervise those at the lower levels. A two-level trial system is applied in Chinese courts, whereby a case is finally decided after two trials, first by a lower court, then by a higher court if there is an appeal. In criminal cases, the

\footnotetext{
48 See Xinhua, 22nd Congress on Law of World Opens, PeOple Daily, Sept. 6, 2005.

49 BLACK'S LAW DICTIONARY 849 (6th ed., 1990).

$50 \quad I d$.

51 See YUAN \& SUN, supra note 28, at 3.

52 See CHEN YeHONG \& TANG Ming, COMPARISON OF CHINESE AND FOREIGN Judicial SYSTEMS 4-6 (2000). Another extreme view limits the judicial system only to "courts." Li Fucheng, A Special Conference on China's Judicial Reform, 12 PEKING U. L.J. 718 (2000).

53 P.R.C. CONST., arts. 123-35 (1982), reprinted in 1 LAWS AND REGULATIONS OF THE PeOPlE'S Republic of CHINA GOVERNing Foreign-Related MATTERS 299-300 (Bureau of Legislative Affairs of the State Council of the P.R.C. ed., 1991).

54 See 1 Judicial WORK OF CONTEMPORARY CHINA 23-24 (He Lanjian \& Lu Mingiian eds., 1993). The People's Supreme Court was established in October 1949 just after the founding of the PRC. $I d$.
} 
procuratorate may present a protest to the higher court when it is dissatisfied with the decision made by the lower court.

Chinese courts have jurisdiction over cases with foreign elements, but, in these cases, the relevant courts may not handle them by invoking international law. In practice, cases applying international law are rare in China, and in most cases, the applicable rules of international law are related to commercial and maritime subject matters. One paper written by legal officers in the Chinese Foreign Ministry describes several commercial and maritime cases in which international treaties are directly invoked. The treaties include, inter alia, the 1980 UN Convention on Contracts for the International Sale of Goods, the 1929 Warsaw Convention on the Unification of Certain Rules Relating to International Carriage by Air, the 1955 Hague Protocol to the Warsaw Convention, the 1974 UN Convention on a Code of Conduct for Liner Conferences, the 1972 Convention on the International Regulations for Preventing Collisions at Sea, and the 1974 International Convention for the Safety of Life at Sea. 55

Besides multilateral international treaties, courts sometimes invoke bilateral agreements to determine cases. For example, in the 1996 case, Twentieth Century Fox Film Corporation v. Beijing Superstore for Cultural and Arts Publications and AV Products Inc., the First Intermediate People's Court of Beijing ruled that the plaintiff's movie products were protected under Chinese law, even if the copyrights were obtained in the United States because China was a party to the Berne Convention and the MOU on the Protection of Intellectual Property signed between China and the United States on January 17, 1992.56

In 1995, the Supreme People's Court, along with the Supreme People's Procuratorate, Ministry of Foreign Affairs, Ministry of Public Security, Ministry of National Security, and Ministry of Justice, jointly issued the Provisions on Certain Questions in Regard to Cases with Foreign Elements, in which Article 3 of Chapter 1 provides that:

in the handling of cases with foreign elements, on the basis of the principle of reciprocity and mutual benefit, international treaty obligations undertaken by China should be strictly observed. In case domestic laws or internal regulations are in conflict with China's treaty obligations, the relevant provisions of international treaties shall prevail, except for those provisions to which China has made reservations. The competent

See Xue \& Jin, supra note 15 , at 310-13.

See id. at 313 . 
authorities shall not invoke domestic laws or internal regulations as a justification for the refusal to perform treaty obligations. ${ }^{57}$

These provisions guide lower courts to apply international treaties. Although the provisions only mention "foreign elements" without specifying what treaties are included, it is generally understood that it refers to the treaties in the maritime and commercial domain. In 2002, the Supreme People's Court issued the Opinions on Certain Issues in the Application of the Civil Procedure Law, which clarified the term "civil relations and cases with foreign elements" to mean civil relations and cases in which: (a) one party or both parties to the dispute are foreign nationals, stateless persons, foreign enterprises, or organizations; (b) the legal facts that establish, modify, or terminate the civil legal relations between the parties arise in foreign territories; or (c) the disputed object of the lawsuit is located in a foreign country. ${ }^{58}$ It is to be noted that these Provisions were issued before China's entry into the WTO, therefore it may not apply to the WTO regulations.

The practice relating to the invocation of international law in Chinese courts is not consistent. Sometimes, Chinese courts even invoked treaties to which China was not yet a party. For instance, in a case concerning a foreign vessel detention in 1985, the Maritime Court in Qingdao established its jurisdiction over the case by invoking Article 28(3) of the 1982 UN Convention on the Law of the Sea (hereinafter "LOS Convention"), in addition to Article 27 of the Civil Procedure Law and an international custom. ${ }^{59}$ At that time, China was not a party to the LOS Convention, though it signed it in 1982.

Apart from the above judicial practice, the question arises as to whether China allows its courts to directly apply international treaties in non-commercial and maritime cases, particularly when Chinese courts deal with human rights cases. The picture is not clear because the cases in this category are very rare. There is, however, a reported case on the trial of sea pirates. The Department of Public Security of the Guangxi Autonomous Region decided to investigate the case according to Article 27 of the LOS Convention (on criminal jurisdiction on board a foreign

\footnotetext{
57 Id. at 315-16 (citing http://www.chinalaw.gov.cn/jsp/contenpub/brower/moreinfo. jsp?page $=2 \&$ id $=\operatorname{co5022565624})$.

58 Id. at 304 (citing http://www.chinalaw.gov.cn/jsp/jalor_en/disptext.jsp?recno= $83 \& \&$ ttlrec $=291$ ).

59 See Qingdao Maritime Court Handles a Case Concerning Foreign Vessel Detention, available at http://www.ccmt.org.cn/hs/news/show.php?cId=49 (last visited Mar. 20, 2009).
} 
ship). ${ }^{60}$ Chinese courts once applied relevant international treaties to try aircraft hijackers because no applicable law could be found in the Chinese Criminal Law.

As for the direct application of human rights treaties, it seems that so far there has not been a case heard by a Chinese court in this regard. According to some Chinese, "international conventions on human rights do not have direct legal force in domestic law[,]" 61 or "in practice, human rights treaties generally may not be directly applied by Chinese courts." 62 One explanation is that fundamental rights enshrined in the Chinese Constitution have yet to be applied directly by Chinese courts. So far Chinese courts have not yet directly applied the Constitution as a legal basis for a case, due to the precedent from a case in 1955 where the Supreme People's Court issued a reply to the Xinjiang Higher Court that it was not appropriate to render criminal punishment by invoking the Constitution as an applicable law. ${ }^{63}$ With the deepening of the legal reform in China, however, the restriction on the application of the Chinese Constitution has been lessened. There was one case in 2001 that touched upon the issue of whether Chinese courts can apply the Constitution.

In Qi Yuling v. Chen Xiaoqi, et. al, the Chinese Supreme Court indicated that the Chinese Constitution could be directly applied in ordinary civil litigation and authorized the Shandong Higher Court to apply a constitutional provision on the right to education in adjudicating a civil lawsuit. ${ }^{64}$ The case has been hailed as the realization of constitutionalism in China. Nevertheless, it is interesting to note that the Supreme Court itself repealed the Reply on December 8, 2008, stating that it ceased to apply.65 This revocation of the application of the Constitution as adjudicative norms indicates that China has returned to the legal state prior to Qi Yuling.

60 See Zou Keyuan, New Developments in the International Law of Piracy, 8(2) CHINESE J. OF INT'L L., 323, 323-45 (2009).

61 Xue \& Jin, supra note 15 , at 309.

62 Sanzhuan Guo, Implementation of Human Rights Treaties by Chinese Courts: Problems and Prospects, 8 (1) CHINESE J. OF INT'L L. 161, 166 (2009).

63 The Reply of the Supreme People's Court on the Inappropriateness to Render Criminal Punishment by Invoking the Constitution as an Applicable Law, (July 30, 1955), http://vip.chinalawinfo.com/newlaw2002/SLC/slc.asp?db=chl\&gid=92.

64 See Thomas E. Kellogg \& Keith Hand, China Crawls Slowly Towards Judicial Reform, ASIAN TIMES, Jan. 25, 2008, available at http://209.85.229.132/search?q=cache:sE_ EnUfAU3UJ:www.atimes.com/atimes/China/JA25Ad01.html+qi+yuling+case\&cd=1\&hl= en\&ct $=\mathrm{clnk} \& \mathrm{gl}=\mathrm{uk}$.

65 See The Decision of the Supreme People's Court on Repealing Certain Judicial Interpretations Issued Prior to the End of 2007 (the 7th Batch), http:/ / www.chinacourt.org/flwk/show.php?file_id=132344 (last visited Feb. 8, 2010). 
Difficulties naturally arise as to the direct application of international human rights law in China since legal issues concerning human rights are still sensitive in China. Chinese courts, dependent on the Chinese Government and the Chinese Communist Party, are reluctant to handle these cases, much less to apply human rights treaties, particularly when the cases are related to the infringements of human rights by government agencies and/or officials. As reported, the winning rate for ordinary citizens in administrative litigation is only about thirty percent. ${ }^{66}$ As is well known, the Chinese Communist Party (hereinafter "CCP") has an internal organization named the Political-Legal Committee, which controls national security, public security, and judicial affairs throughout the country. ${ }^{67}$ The Chinese judiciary is not as independent as courts in democratic countries. The reliance of courts on the CCP and the government can be seen from the issuance of judicial directives on the application of international law as mentioned above, which was not issued by the Supreme Court alone or with the Supreme Procuratorate, but jointly with some government departments. Another deterrent factor is the low professional quality of Chinese judges. Mishandled cases have frequently been reported. In Heilongjiang Province, for instance, between 1993 and 1996, sentences given in 438 court cases were found to be erroneous and 460 judicial officials were punished for malpractice. ${ }^{68}$ The majority of the judges are not legal experts in international law and they are still in a learning process to familiarise themselves with that new area of law. Finally, it should be noted that there is some reluctance for the Chinese judiciary to apply international law. This can be seen from a popular view expressed by a Chinese judge: an international treaty cannot have the effect of direct application in Chinese courts unless there is an express consent by the National People's Congress when it ratifies a treaty or when there are relevant provisions set forth by the competent government department on whether that treaty should be directly applied or prevail over relevant domestic law; a court may not consider any corresponding international responsibility that China may possibly bear as it breaches the treaty obligation due to the refusal by the court of applying the treaty. ${ }^{69}$ For

\footnotetext{
66 See Zou Keyuan, Administrative Reform and Rule of Law in China, 24 COPENHAGEN J. ASIAN STUD. 5, 20-21 (2006).

67 See Zou KeyUAN, CHINA's Legal ReForm: TOWARds the Rule of LAW $59-67$ (2006).

68 Liu Junhai, Legal Reforms in China, in GOVERNANCE, DECENTRALIZATION AND REFORM IN CHINA, INDIA AND RUSSIA 395 (Jean-Jacques Dethier ed., 2000).

69 Wu Yarong, Legal Effect of WTO Agreements and Their Application in Chinese Courts, in Judicial ResearCh ON WTO AND the ChINESE Legal System 157, 160 (Cao Jianmin ed., 2001).
} 
human rights cases, courts usually directly apply the relevant national laws to redress any infringement of individual rights. ${ }^{70}$

\section{CONCLUSION}

The implementation of international law needs the sincere efforts of individual nation-states. The 2005 World Summit called for universal adherence to and implementation of the rule of law at both the national and international levels. ${ }^{71}$ According to China, for the rule of law at the international level, several undertakings need to be fulfilled: (1) maintaining the authority of the UN Charter; (2) enhancing the democratization of international relations; (3) strictly abiding by international treaties and international customary rules and UN Security Council decisions with binding force; (4) ensuring the consistent application of international law; and (5) further improving "international legislation."72 China's positive attitude towards the rule of law at the international level has its domestic background. Since 1978, China has carried out legal reform and adopted the concept of the rule of law in its Constitution. Legal awareness of ordinary citizens in China has increased significantly. Inevitably, achievements of legal reform at the domestic level influence a nation-state's practice in international law. In this sense, the realization of the rule of law at the international level depends on the rule of law process at the national level.

Notwithstanding the above, there is a gap in China's implementation of international law, in particular international human rights law. China faces a dilemma in its response to the development of international law. On the one hand, it realizes that international law is developing with the globalization of the world community and new branches have emerged, such as law relating to human rights and to environmental protection. On the other hand, it seems that China is not fully ready to respond to such new developments, particularly in the field of human rights law. ${ }^{73}$ At the time of this writing, China has not yet ratified the ICCPR. Even if China's ratification had been inked, there would still be a problem of effective implementation of the ICCPR at the national level. It is remembered that, despite China's ratification of the UN Convention Against Torture and Other Cruel, Inhuman, or Degrading Treatment or

See Xue \& Jin, supra note 15, at 310.

The General Assembly, 2005 World Summit Outcome, $₫ 134$ U.N. Doc. A/RES/60/1, A 160/L.1 24 (Oct. 24, 2005).

72 See Speech of the Chinese Delegate Duan Jielong at the Sixth Committee of the 61st UN General Assembly on 'the Rule of Law at the National and International Levels' (Oct. 17, 2006), http://www.fmprc.gov.cn/chn/wjb/zzjg/tyfls/lcybt/t283190.htm.

73 ZOU, supra note 67 , at 248 . 
Punishment, as early as 1988, torture in China remains common and subjected to strong international criticism. Having realised there exists a huge gap in the effective implementation of international human rights law, China published for the first time the Plan of Action in Human Rights in April 2009 for the period between 2009 and 2010, pledging to further improve the human rights conditions in China. ${ }^{74}$

Since the 1990s, China has carried out its judicial reform and the pace has been quickened after China's entry into the WTO in 2002. In March 2009, the Supreme Court disseminated the Third Five-Year Programme of People's Court Reform (2009-2013). ${ }^{75}$ One of the goals for such reform is to realise judicial professionalism. It is perceived that with more and more judges who are familiar with international law, the chance of the application of international law will be greater than ever. Following this vein, the direct application of international human rights law by Chinese courts may not be a remote possibility after China has ratified the ICCPR in the near future. Associated with this is the realization of judicial independence, which no doubt can facilitate the application of international law, in particular international human rights law, before Chinese domestic courts.

74 For the whole text, see http://politics.people.com.cn/GB/1026/9123722.html (last visited Feb. 8, 2010).

75 For the text, see http://news.xinhuanet.com/legal/2009-03/26/content_11074127. htm (last visited Feb. 8, 2010). 